\title{
Solid electrolyte interphase formation on metallic lithium
}

\author{
Andrzej Lewandowski • Agnieszka Swiderska-Mocek • \\ Lukasz Waliszewski
}

Received: 13 April 2012 /Revised: 17 May 2012 / Accepted: 23 May 2012 / Published online: 8 June 2012

(C) The Author(s) 2012. This article is published with open access at Springerlink.com

\begin{abstract}
Solutions of three salts $\left(\mathrm{LiBF}_{4}, \mathrm{LiNTf}_{2}, \mathrm{LiPF}_{6}\right)$ in $\mathrm{N}$-methyl-2-pyrrolidone (NMP), selected arbitrarily as a reference solvent, were investigated by electrochemical impedance spectroscopy (EIS) and scanning electron microscopy techniques. The lithium surface in contact with $\mathrm{LiPF}_{6}$ in NMP electrolyte was covered with a protective layer (SEI) which morphology comprise small particles (of ca. $0.2 \mu \mathrm{m}$ in radius). This salt was selected for further studies. The impedance of the $\mathrm{Li} \mid\left(\mathrm{LiPF}_{6}\right.$ in $\mathrm{NMP}+$ additive $) \mid \mathrm{Li}$ system was measured immediately after cell assembly and after galvanostatic charging/discharging. Fifteen different additives $(10 \mathrm{wt} . \%)$ were used. The efficiency of individual additives was evaluated in terms of the Li|electrolyte system resistance $(\Delta R)$ or total cell impedance reduction, both deduced from EIS. Some of the additives were able to form the SEI layer and to reduce resistance/impedance of the $\mathrm{Li} \mid$ electrolyte interphase. In such cases, the lithium surface was covered with relatively uniform conglomerates, or regions separated by cracks, of ca. $1-2 \mu \mathrm{m}$ in dimension.
\end{abstract}

Keywords Lithium $\cdot$ SEI $\cdot$ Electrolyte additive $\cdot$ EIS

\section{Introduction}

Both lithium-metal and lithiated graphite anodes applied in lithium or Li-ion batteries react with electrolytes with the formation of a passivation layer, usually called the solid electrolyte interphase (SEI), protecting them against further

A. Lewandowski $(\bowtie) \cdot$ A. Swiderska-Mocek $\cdot$ L. Waliszewski Faculty of Chemical Technology,

Poznan University of Technology,

60965 Poznan, Poland

e-mail: andrzej.lewandowski@put.poznan.pl corrosion $[1,2]$. Cyclic carbonates, typically used as components (solvents) of lithium electrolytes, react with $\mathrm{Li}$ or $\mathrm{C}_{6} \mathrm{Li}$ anodes with the formation of $\mathrm{Li}^{+}$conducting SEI [3-8]. The SEI layer is responsible for the chemical and electrochemical stability of electrodes. However, SEI forming cyclic carbonates are volatile and hence, the system is flammable (during overheating, overcharging, or mechanical damage). Therefore, for safety reasons, all components of a Li-ion battery, including the electrolyte, should be characterised by non-flammability. The non-volatility of room temperature ionic liquids is important from the point of view of their possible application as non-flammable electrolytes in lithium and Li-ion batteries [9-12]. Another approach is to find a low vapour pressure molecular solvent, for example $\gamma$ butyrolactone $\left(\gamma-\mathrm{BL}, T_{\mathrm{b}}=205{ }^{\circ} \mathrm{C}\right)$ [13] or tetramethylene sulfone (TMS, $T_{\mathrm{b}}=280{ }^{\circ} \mathrm{C}$ ) [14]. However, unconventional systems, such as ionic liquids and high boiling point solvents $(\gamma$-BL, TMS) do not form SEI protective layer but rather resistive corrosion products. Therefore, in non-classical electrolytes additives are necessary to improve $\mathrm{Li}$ and Li-ion battery performance $[6,15]$. The general aim of the present study was to provide visual (scanning electron microscopy, SEM) and quantitative (electrochemical impedance spectroscopy, EIS) comparison of additives in an arbitrarily selected solvent ( $\mathrm{N}$-methyl pyrrolidone). The effect of the additive presence on the Li|electrolyte impedance may be used as a measure of its SEI forming properties.

\section{Experimental}

Materials

Lithium foil ( $0.75 \mathrm{~mm}$ thick, Aldrich), lithium hexafluorophosphate $\left(\mathrm{LiPF}_{6}\right.$, battery grade $>99 \%$, Fluka), vinylene 
carbonate (VC, $>97 \%$, Aldrich), vinyl ethylene carbonate (VEC, $>99 \%$, Aldrich), ethylene carbonate (EC, anhydrous $99 \%$, Aldrich), propylene carbonate (PC, anhydrous 99,7\%, Aldrich), dimethyl carbonate (DMC, anhydrous $>99 \%$, Aldrich), diethyl carbonate (DEC, anhydrous $>99 \%$, Aldrich), ethylene sulphite (ES, $98 \%$, Aldrich), vinyl acetate (Vac, $>99 \%$, Fluka), gamma-butyrolactone ( $\gamma$-BL, $>99 \%$, Aldrich), triphenyl phosphate (TPhPh, Aldrich), phenyl isocyanate (PhIsCy, $>99 \%$, Fluka), methyl cinnamate (MCin, $>99 \%$, Aldrich), dimethyl sulfoxide (DMSO, Merck), and styrene ( $>99 \%$, Aldrich) were used as received. Electrolyte was obtained by dissolution of the solid $\mathrm{LiPF}_{6}$ salt in $N$-methyl-2-pyrrolidone (NMP, Fluka) ( $1 \mathrm{M}$ solution of $\mathrm{LiPF}_{6}$ salt in NMP). Electrolytes were prepared in a dry argon atmosphere in a glove box. They contained various additives (VC, VEC, EC, PC, DMC, DEC, ES, Vac, $\gamma$-BL, TPhPh, PhIsCy, MCin, DMSO, styrene) at $10 \mathrm{wt} . \%$.

\section{Measurements}

The performances of the cells were characterized using electrochemical impedance spectroscopy (EIS) and using galvanostatic charge-discharge tests. The Li/electrolyte/Li cells were assembled in a dry argon atmosphere in a glove box. Two lithium foils were separated by the glass microfibre GF/A separator (Whatman), placed in an adopted 0.5" Swagelok ${ }^{\circledR}$ connecting tube. Interface resistance at the electrode/electrolyte interphase was measured using an ac impedance analyzer (Atlas-Sollich system, Poland). The Li/ electrolyte/Li cells were polarised with a constant current (1 $\mathrm{mA}$ ) for $45 \mathrm{~min}$ and for the next $45 \mathrm{~min}$ in the opposite direction. Scanning electron microscopy (SEM) of the lithium electrode was performed with the Tescan Vega 5153 apparatus. After electrochemical measurements, cells were disassembled, electrodes washed with DMC and dried in vacuum at room temperature. All operations were performed in a dry argon atmosphere in a glove box.

\section{Results}

Salt effect

Figure 1 shows impedance spectra of the $\mathrm{Li}|\mathrm{NMP}+\mathrm{LiX}| \mathrm{Li}$ system $\left(\mathrm{LiX}=\mathrm{LiBF}_{4}, \mathrm{LiNTf}_{2}, \mathrm{LiPF}_{6}\right)$ taken immediately after the cell assembling and after its galvanostatic charging/discharging. In the case of all salts, the impedance of the system increased after the electrochemical SEI formation. The impedance of the fresh system (without galvanostatic polarisation) may be interpreted as a result of lithium reaction with the electrolyte (solvent and salt) with the formation of a passivation layer. The highest impedance is characteristic
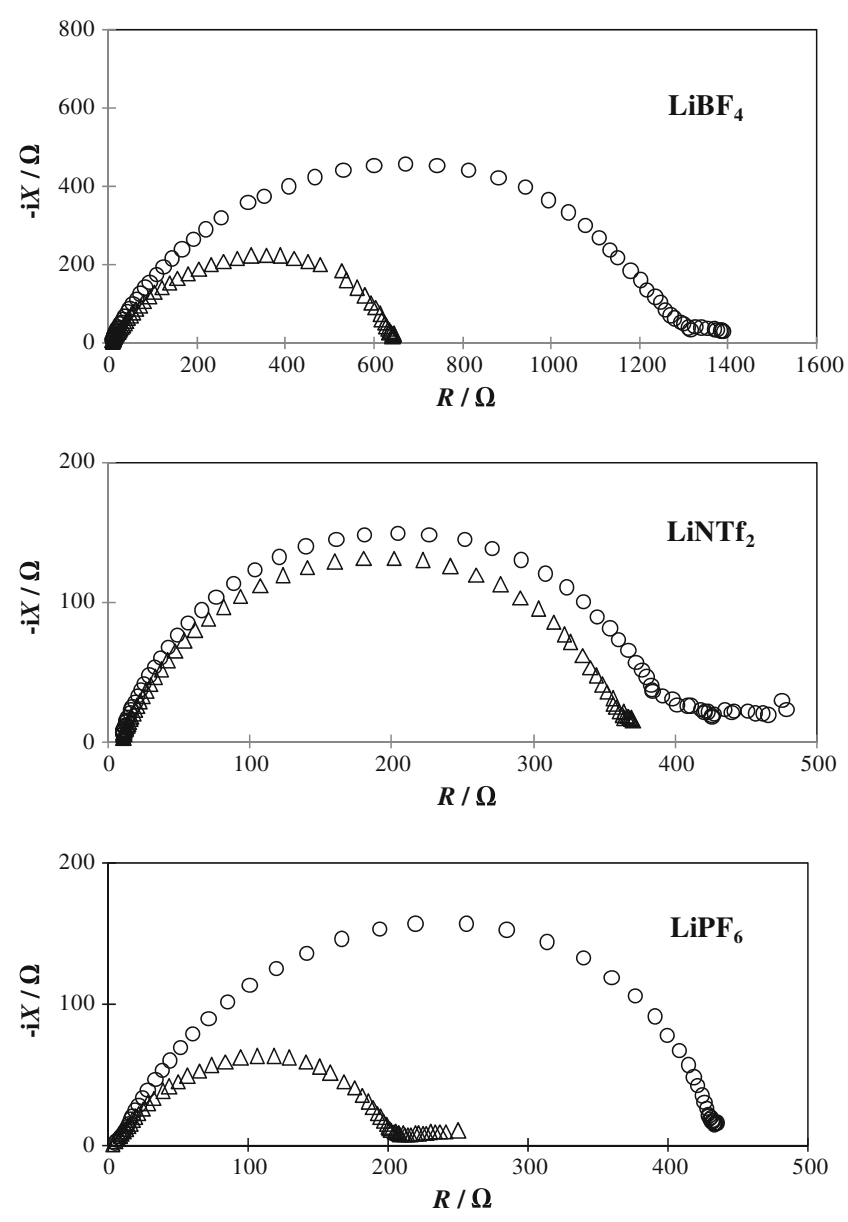

Fig. 1 Impedance spectra of the Li|NMP + LiX|Li system taken immediately after cell assembling $(\Delta)$ and after its galvanostatic charging/discharging (o). Current, $1 \mathrm{~mA} \mathrm{~cm}{ }^{-2}$, charging/discharging time, 45 min. LiX stands for $\mathrm{LiBF}_{4}, \mathrm{LiNTf}_{2}$ or $\mathrm{LiPF}_{6}$

of the $\mathrm{Li} \mid\left(\mathrm{LiBF}_{4}\right.$ in NMP) system (of the order of $600 \Omega$ referred to $1 \mathrm{~cm}^{2}$ of the lithium geometrical surface area). In the case of the solutions of the other salts $\left(\mathrm{LiNTf}_{2}\right.$ or $\left.\mathrm{LiPF}_{6}\right)$, it is lower (ca. 400 and $200 \Omega$, respectively). During the electrochemical charging/discharging, the passivation layer is modified as a result of (1) the thickness, (2) composition (solid lithium salts and polymers), (3) and morphology changes. As a result of the lithium/electrolyte interphase modification, the total resistance (impedance) also changes. In the case of $\mathrm{LiBF}_{4}$ and $\mathrm{LiPF}_{6}$ salts, the total impedance increases by ca. $100 \%$. The corresponding value for $\mathrm{LiNTf}_{2}$ salt is much smaller. SEM images of lithium metal surface covered with corrosion products after a chemical reaction with the NMP + LiX electrolyte (without electrochemical charging/discharging) are shown in Fig. 2. It can be seen that metallic lithium, after its contact with NMP solutions of $\mathrm{LiBF}_{4}$ and $\mathrm{LiNTf}_{2}$ salts, reacts with the formation of a uniform passivation film. In the case of the $\mathrm{LiPF}_{6}$ in NMP electrolyte, the lithium surface is covered with small particles (of ca. $0.2 \mu \mathrm{m}$ in radius). This may suggest that in the case of $\mathrm{Li}^{(}\left(\mathrm{LiPF}_{6}\right.$ in NMP), the specific 


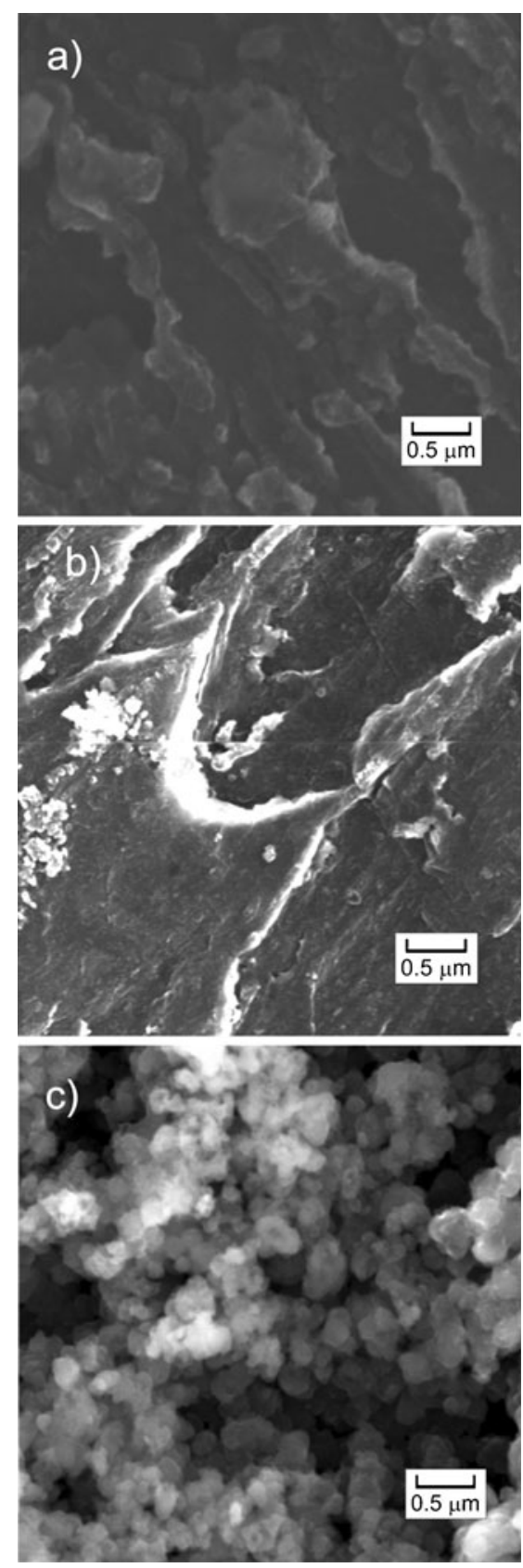

Fig. 2 SEM images of lithium metal surface covered with corrosion products after chemical reaction with NMP + LiX electrolyte (without electrochemical charging/discharging) (a) NMP $+1 \mathrm{M} \mathrm{LiBF}_{4}$; (b) $\mathrm{NMP}+1 \mathrm{M} \mathrm{LiNTf}_{2}$ and (c) NMP $+1 \mathrm{M} \mathrm{LiPF}_{6}$. Magnification, $13,000 \times$

morphology (particles instead of the film layer) is due to the formation of Li salt solid particles (for example LiF) surrounded by a polymer film [3, 16-18].

\section{Additives}

Impedance spectra of $\mathrm{Li}\left|\mathrm{NMP}+\mathrm{LiPF}_{6}+\mathrm{VC}(10 \mathrm{wt} . \%)\right| \mathrm{Li}$ and $\mathrm{Li} \mid \mathrm{NMP}+\mathrm{LiPF}_{6}+\mathrm{Vac}(10$ wt. $\%) \mid \mathrm{Li}$ are shown in Fig. 3. It can be seen that the impedance taken immediately after cell assembly is higher in comparison to that characteristic of the electrochemically cycled cell (1 charging and 1 discharging cycle). This suggests that electrochemically prepared SEI is more conductive in comparison to the spontaneously formed passivation films. The ohmic resistance values of the freshly prepared $\mathrm{Li} \mid$ electrolyte systems were ca. 120 and $300 \Omega$ for $\mathrm{VC}$ and Vac as additives, respectively. SEI resistance (after charging/discharging) is considerably lower (ca. $80 \Omega$ for VC and ca. $50 \Omega$ for Vac). In contrast to such a behaviour, in some cases, the electrochemical charging/ discharging led to an increase in the total system impedance. The $\mathrm{Li} \mid \mathrm{NMP}+\mathrm{LiPF}_{6}+\mathrm{ES}(10$ wt.\%)|Li and $\mathrm{Li} \mid \mathrm{NMP}+$ $\mathrm{LiPF}_{6}+\mathrm{ES}(10 \mathrm{wt} . \%) \mid \mathrm{Li}$ systems may serve as examples. Here, the ohmic resistance increased to $220 \Omega$ (PC) or even $300 \Omega$ (ES) (Fig. 4). All impedance spectra consist of a flat 'semicircle', usually followed by a short linear part at a low frequency region. The high and medium frequency part may be approximated by a semi-ellipse rather than the semi-circle, as its major radius (the real axis $R$ ) does not equal the minor radius (the imaginary axis-iX). Typically, the value (expressed in ohms) of the major radius is higher than the corresponding value of the minor radius $\left(\mathrm{R}^{2}>(\mathrm{i} X)^{2}\right)$. This may suggest that the semi-elipse is a superposition of two semicircles, representing two $R C$ elements in a series, due to the SEI formation and a charge transfer process (Fig. 5). The frequency range of the linear-part is relatively narrow and the slope is much below $45^{\circ}$. The linear, low-frequency part, obtained for the reduction of $\mathrm{Li}^{+}$on the metal-lithium anode is different from that characteristic of graphite anodes, where the
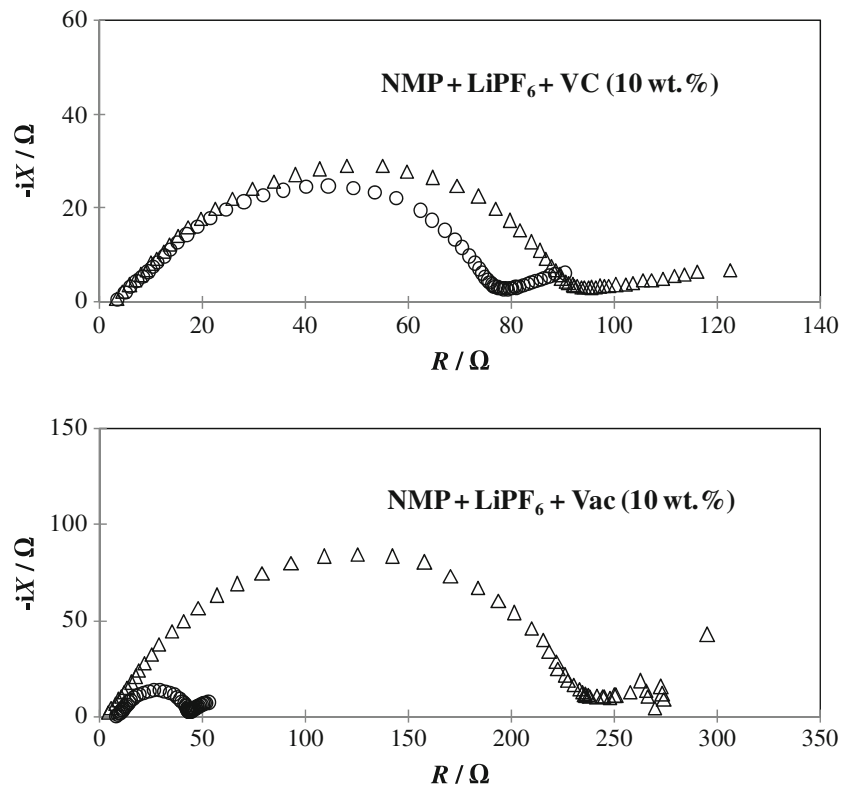

Fig. 3 Impedance spectra of $\mathrm{Li}\left|\mathrm{NMP}+\mathrm{LiPF}_{6}+\mathrm{VC}(10 \mathrm{wt} . \%)\right| \mathrm{Li}$ and $\mathrm{Li}\left|\mathrm{NMP}+\mathrm{LiPF}_{6}+\mathrm{Vac}(10 \mathrm{wt} . \%)\right| \mathrm{Li}$ cells taken immediately after cell assembling $(\Delta)$ or after its galvanostatic charging/discharging (o). Current, $1 \mathrm{~mA} \mathrm{~cm}{ }^{-2}$, charging/discharging time, $45 \mathrm{~min}$ 

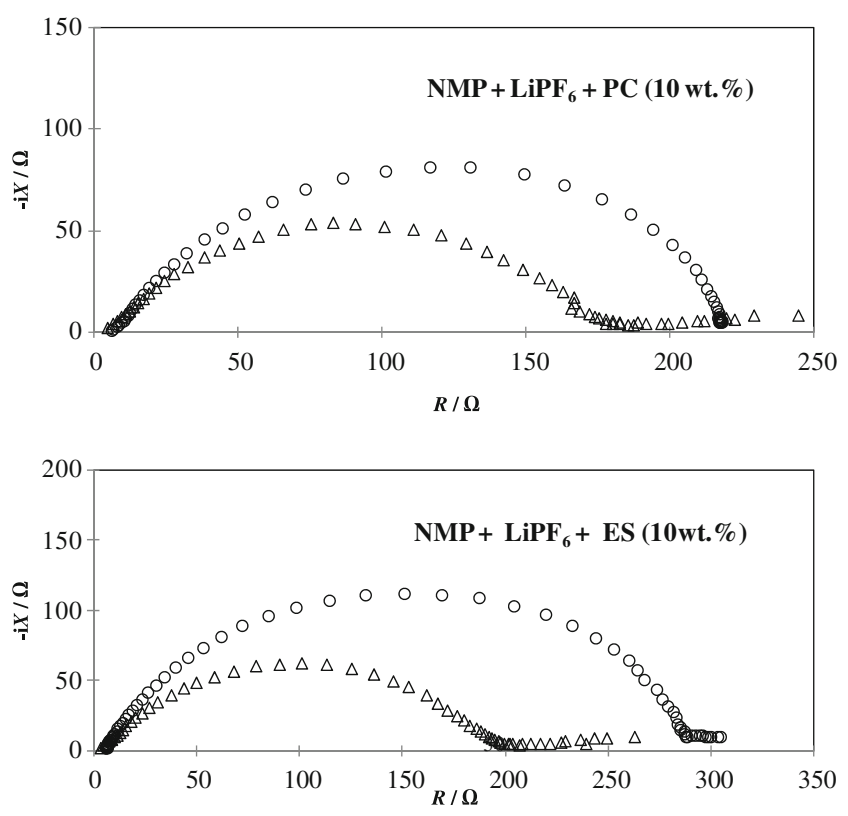

Fig. 4 Impedance spectra of $\mathrm{Li}\left|\mathrm{NMP}+\mathrm{LiPF}_{6}+\mathrm{PC}(10 \mathrm{wt} . \%)\right| \mathrm{Li}$ and $\mathrm{Li}\left|\mathrm{NMP}+\mathrm{LiPF}_{6}+\mathrm{ES}(10 \mathrm{wt} . \%)\right| \mathrm{Li}$ cells taken immediately after cell assembling $(\Delta)$ or after its galvanostatic charging/discharging (o). Current, $1 \mathrm{~mA} \mathrm{~cm}^{-2}$, charging/discharging time, $45 \mathrm{~min}$

Warburg impedance is predominant due to lithium diffusion in solid graphite [19]. This may suggest that low-frequency linear parts of impedance spectra shown in Figs. 1, 3, 4 and 8 cannot be described by the Warburg element $Z_{\mathrm{W}}$, but rather by an element $Z$ (without ascribing any physical meaning). However, commercial software packages used for impedance data deconvolution generally contain the $Z_{\mathrm{W}}$ element for the description of the low frequency region. Due to the fact that the low frequency part of impedance plots measured for the Li-metal| $\mathrm{Li}^{+}$systems does not exhibit a Warburg-like nature, two attempts for experimental plot deconvolution were made. First, the data measured in the whole frequency region were analysed with $Z=Z_{\mathrm{W}}$. In the second attempt, both the low frequency region data (the linear part of spectra) and the $Z$ element in the equivalent circuit were excluded from the fitting procedure. Both attempts led to very similar $R_{\mathrm{SEI}}$ and $R_{\mathrm{ct}}$ values. In addition, standard deviations of calculated and experimental impedances were comparable. Total impedances (Imp), measured at a frequency of $0.1 \mathrm{~Hz}$, before and after galvanostatic charging/discharging of $\mathrm{Li} \mid \mathrm{NMP}+\mathrm{LiPF}_{6}+$ additive (10 wt.\%)|Li systems, for 15 additives studied, are

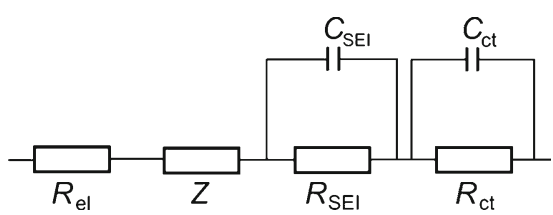

Fig. 5 An equivalent circuit representing the Li/electrolyte system summarised in Table 1. Values of SEI ohmic resistance $R_{\mathrm{SEI}}$ and charge transfer resistance $R_{\mathrm{ct}}$, obtained from the deconvolution procedure, are also shown in Table 1. Total impedance (Imp) measured at a low frequency of $0.1 \mathrm{~Hz}$ immediately after the Li|electrolyte|Li cell assembling, is typically of the order of 200-300 $\Omega$. In the case of the VC containing electrolyte, its value is lower $(120 \Omega)$ while electrolytes based on EC and $\mathrm{Vac}+\mathrm{VC}$ additives show considerably higher impedance (ca. $600 \Omega$ ). After galvanostatic charging/discharging, the total impedance decreases (VC, EC, PC, $\gamma$-BL, TPhPh, PhIsCy, Vac, Vac+VC) or increases (DEC, DMC, VEC, DMSO, ES, MCin, styrene). The electrochemical SEI formation led to the lowest total impedance in the case of VC $(91 \Omega)$ and Vac $(53 \Omega)$. On the other hand, in the case of styrene as the additive, the electrochemical treatment resulted in impedance increasing up to $613 \Omega$ (from an initial value of $239 \Omega$ ). A similar decrease of the $R_{\mathrm{SEI}}+R_{\mathrm{ct}}$ ohmic resistance drop after electrochemical charging/discharging $\left(\Delta R=\left(R_{\mathrm{SEI}}+R_{\mathrm{ct}}\right)_{\text {after }}\right.$ $\left.\left(R_{\mathrm{SEI}}+R_{\mathrm{ct}}\right)_{\text {before }}\right)$ for cells with electrolytes containing the same additives (except PC) was observed (Table 1). Negative $\Delta \operatorname{Imp}$ or $\Delta R$ values suggest a replacement of the less conductive passivation layer by electrochemically formed SEI. Figures 6 and 7 show examples of SEM images of the lithium layer after electrochemical SEI formation from electrolytes $\left(\mathrm{NMP}+\mathrm{LiPF}_{6}\right)$ containing additives reducing $(\mathrm{VC}$ and $\mathrm{Vac}$, Fig. 6) or increasing (PC and ES, Fig. 7) ohmic resistance. While the metallic lithium in the NMP+ $+\mathrm{LiPF}_{6}$ electrolyte is covered with spherical particles (Fig. 2c), the SEI structure (formed electrochemically, shown in Figs. 6 and 7) is different. In the case of $\mathrm{VC}$ as the additive, the lithium surface is covered with smooth and uniform regions, separated by cracks, of ca. 1-2 $\mu \mathrm{m}$ in dimension, one order of magnitude higher in comparison to that characteristic of spherical particles formed without VC. On the other hand, the morphology of the SEI structure formed in the presence of Vac was a foamlike, organised in conglomerates of a comparable dimension $(1-2 \mu \mathrm{m})$. A similar morphology may be observed in the case of PC and ES as additives. Ohmic resistance in the case of PC as the additive increases after galvanostatic charging/discharging $(\Delta R>0)$, but the corresponding total impedance change is negative $(\Delta \operatorname{Imp}<0)$. In all the other cases negative $\Delta R$ corresponds to negative $\Delta$ Imp values. While the electrochemical pre-treatment of the Li|electrolyte system resulted always in the formation of the more uniform morphology, the corresponding impedance increased or decreased. In general, electrochemical SEI formation results in a morphology change from spherical $(0.2 \mu \mathrm{m})$ into a more uniform system $(1-2 \mu \mathrm{m})$. This effect was observed before for the graphite $[17,18]$ and silicone [16] anodes. The passivation layer formed in a classical $\mathrm{LiPF}_{6}$ solution in $\mathrm{EC}+\mathrm{DMC}$ electrolyte without any additive was non-homogeneous and embedded with spherical particles, which were assumed to be LiF crystals. SEM images of the SEI layer formed on the graphite and 
Table 1 Total $\mathrm{Li} \mid \mathrm{NMP}+\mathrm{LiPF}_{6}+$ additive $(10 \mathrm{wt} . \%) \mid \mathrm{Li}$ cell impedance (Imp), together with corresponding resistances of the SEI layer $\left(R_{\mathrm{SEI}}\right)$ and charge transfer process $\left(R_{\mathrm{ct}}\right)$, measured before and after its electrochemical formation (galvanostatic charging/discharging) (lithium electrodes surface area, $1 \mathrm{~cm}^{2}$ )

\begin{tabular}{|c|c|c|c|c|c|c|c|c|}
\hline \multirow[t]{2}{*}{ Additives } & \multicolumn{3}{|c|}{ Before charge/discharge $[\Omega]$} & \multicolumn{3}{|c|}{ After charge/discharge $[\Omega]$} & \multicolumn{2}{|c|}{ Difference $[\Omega]$} \\
\hline & $R_{\mathrm{SEI}}$ & $R_{\mathrm{ct}}$ & $\operatorname{Imp}$ & $R_{\mathrm{SEI}}$ & $R_{\mathrm{ct}}$ & $\operatorname{Imp}$ & $\Delta R^{\mathrm{a}}$ & $\Delta \operatorname{Imp}^{\mathrm{b}}$ \\
\hline- & 41 & 149 & 250 & 27 & 363 & 430 & 200 & 180 \\
\hline $10 \% \mathrm{VC}$ & 35 & 53 & 123 & 24 & 47 & 91 & -17 & -32 \\
\hline $10 \% \mathrm{DEC}$ & 46 & 83 & 171 & 48 & 160 & 225 & 79 & 54 \\
\hline $10 \% \mathrm{DMC}$ & 44 & 136 & 188 & 100 & 240 & 379 & 160 & 191 \\
\hline $10 \% \mathrm{EC}$ & 129 & 275 & 569 & 68 & 235 & 326 & -101 & -243 \\
\hline $10 \% \mathrm{PC}$ & 46 & 118 & 245 & 48 & 161 & 217 & 45 & -28 \\
\hline $10 \% \mathrm{VEC}$ & 30 & 152 & 271 & 25 & 366 & 411 & 209 & 140 \\
\hline $10 \% \gamma$-BL & 29 & 152 & 287 & 10 & 126 & 147 & -45 & -140 \\
\hline $10 \%$ DMSO & 23 & 146 & 246 & 39 & 243 & 280 & 113 & 34 \\
\hline $10 \% \mathrm{ES}$ & 39 & 143 & 263 & 63 & 214 & 305 & 95 & 42 \\
\hline $10 \% \mathrm{TPhPh}$ & 80 & 157 & 253 & 32 & 137 & 185 & -68 & -68 \\
\hline $10 \%$ PhIsCy & 79 & 113 & 253 & 56 & 77 & 170 & -59 & -83 \\
\hline $10 \%$ MCin & 26 & 139 & 241 & 39 & 367 & 310 & 241 & 69 \\
\hline $10 \% \mathrm{Vac}$ & 26 & 188 & 273 & 7 & 32 & 53 & -175 & -220 \\
\hline $5 \% \mathrm{Vac}+5 \% \mathrm{VC}$ & 166 & 225 & 671 & 93 & 183 & 310 & -115 & -361 \\
\hline $10 \%$ styrene & 22 & 80 & 239 & 111 & 350 & 613 & 359 & 374 \\
\hline
\end{tabular}

a $\Delta R=\sum R_{\text {after }}-\sum R_{\text {before }}$ (difference in totalresistance, measured before and after electrochemical polarization)

${ }^{\mathrm{b}} \Delta \mathrm{Imp}=\mathrm{Imp}_{\mathrm{after}}-\operatorname{Imp}_{\mathrm{before}}($ difference of impedance at $0.1 \mathrm{~Hz}$, measured before and after electrochemical polarization)

Imp is total system impedance

silicone in electrolytes containing VC showed rather a smooth and uniform morphology [16-18]. Generally, the microscopic techniques (SEM) show changes in the surface morphology, but do not provide information on the layer impedance. In the case of all additives tested, the spherical-like particles were transformed (during galvanostatic charging/discharging) into much more uniform structures. However, the ohmic resistance or total system impedance may increase or decrease. Therefore, the resistance/impedance decrease may serve as the criterion of the anode (lithium) surface improvement from the point of view of its ability to conduct $\mathrm{Li}^{+}$cations through the SEI layer before the charge transfer reaction. The efficiency of additives, from the point of view of reducing metalliclithium resistance $(\Delta R)$, suggested by EIS analysis is the following: $\mathrm{Vac}>\mathrm{Vac}+\mathrm{VC}>\mathrm{EC}>\mathrm{TPhPh}>\mathrm{PhIsCy}>\gamma-\mathrm{BL}>$ $\mathrm{VC}$. The other compounds did not show any improvement (decrease) of the Lil( $\mathrm{LiPF}_{6}$ in NMP) system resistance (impedance). This is difficult to compare these results with literature data due to the variety of solvents, salts and electrochemical conditions applied. In addition, there are very few works testing metallic-lithium [20-22], while in the case of the graphite anode, there are numerous studies. In the latter case attention is focused on charging/discharging efficiency [23-29], SEM observations of the graphite surface [8, 14, 23-25, 27, 29-31] and EIS analysis [23, 24, 29, 30, 32-35].
In addition, in some papers, only the $\mathrm{LiC}_{6}$ anode was studied $[11,23-25,27-30]$, while in others, the complete cell was tested [13, 36-41]. The additives improving $\mathrm{Li}$ and $\mathrm{LiC}_{6}$ performance were usually tested in electrolytes based on cyclic carbonates or carbonate mixtures, exhibiting SEI forming properties by themselves. However, in the case of ionic liquids as electrolytes, additives seem to be necessary for the functioning of anodes or the Li-ion cell [9-12, 24-28, 30, 39, 42-44]. Among compounds tested, VC seems to be the most popular and effective additive.

Impedance changes with time

Independently of the additive used, ohmic resistance of the SEI layer increases with time (Fig. 8). Evolution of the $\mathrm{Li} \mid$ $\mathrm{NMP}+\mathrm{LiPF}_{6}+\mathrm{VC}(10 \mathrm{wt} . \%) \mid \mathrm{Li}$ cell impedance, measured for the system without electrochemical SEI formation can be seen on Fig. 8a. The ohmic resistance measured immediately after the cell assembling was ca. $120 \Omega$ and the corresponding reactance was ca. $30 \Omega$. During cell storage, the total impedance increased with time by one order of magnitude; ohmic resistance to ca. $2 \mathrm{k} \Omega$ and reactance to ca. $600 \Omega$ (after 12 days). In the case of the same cell with the SEI layer formed electrochemically, the impedance evolution was considerably smaller (Fig. 8b): ohmic resistance 

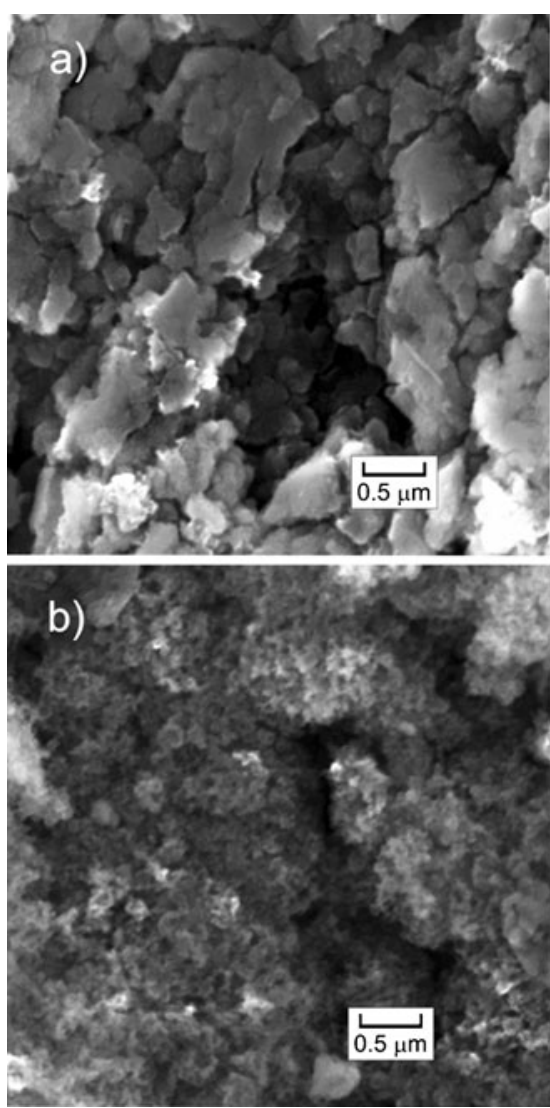

Fig. 6 SEM images of lithium metal surface after its electrochemical charging/discharging in electrolytes containing additives: NMP $+1 \mathrm{M}$ $\mathrm{LiPF}_{6}+$ additive(10 wt.\%); (a) VC, (b) Vac. Magnification, 13,000×

increased to ca. $400 \Omega$ and reactance to ca. $130 \Omega$ (after 13 days). This indicates that the electrochemical formation of SEI protects the Li|electrolyte system against its aging (demonstrated as the total impedance increase).

\section{Conclusions}

1. Solutions of three salts $\left(\mathrm{LiBF}_{4}, \mathrm{LiNTf}_{2}, \mathrm{LiPF}_{6}\right)$ in NMP (not forming SEI layer), selected arbitrarily as a reference solvent, were investigated by EIS and SEM techniques. The lithium surface in contact with the $\mathrm{LiPF}_{6}$ in NMP electrolyte was covered with small particles (of ca. $0.2 \mu \mathrm{m}$ in radius).

2. The $\mathrm{Li} \mid\left(\mathrm{LiPF}_{6}\right.$ in $\mathrm{NMP}+$ additive $) \mid \mathrm{Li}$ impedance taken immediately after cell assembling and after galvanostatic charging/discharging showed differences in ohmic resistance and total impedance. The presence of the following additives: Vac, $\mathrm{Vac}+\mathrm{VC}, \mathrm{EC}, \mathrm{TPhPh}, \mathrm{PhIsCy}$, $\gamma$-BL, VC resulted in a decrease of Lilelectrolyte resistance. The other tested compounds (DEC, DMC, PC, EC, DMSO, ES, MCin, styrene) did not show any reduction of the resistance (impedance).
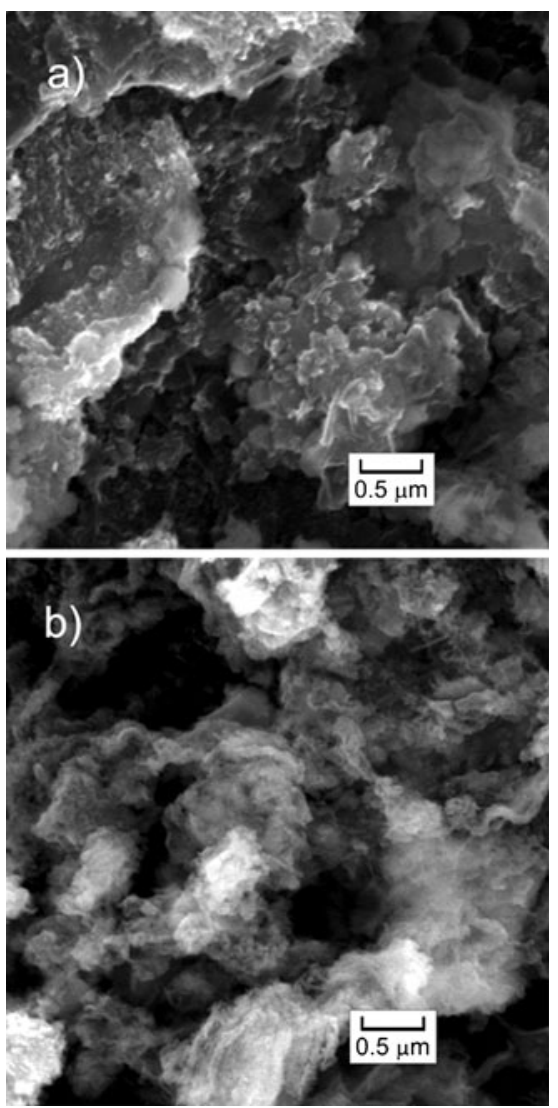

Fig. 7 SEM images of lithium metal surface after its electrochemical charging/discharging in electrolytes containing additives: NMP $+1 \mathrm{M}$ $\mathrm{LiPF}_{6}+$ additive(10 wt.\%); (a) PC, (b) ES. Magnification, 13,000×
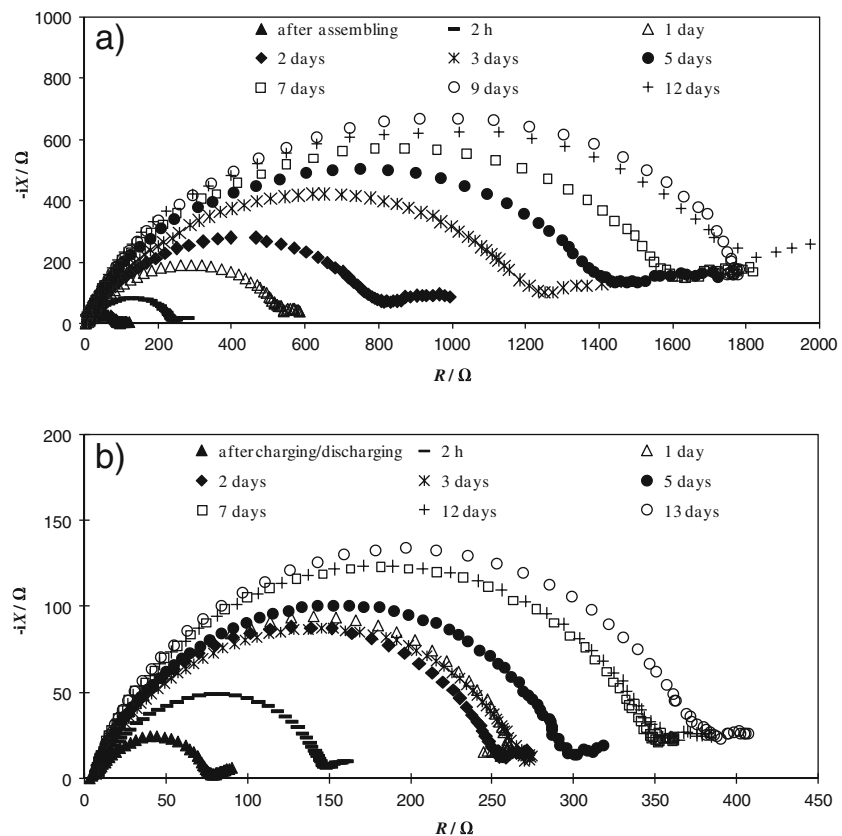

Fig. 8 Impedance evolution of the Li|NMP + $\mathrm{LiPF}_{6}+\mathrm{VC}(10$ wt.\%) Li cell as a function of storage time: (a) Li without SEI (b) Li protected by SEI formed electrochemically. The system was kept under open circuit conditions 
3. In the case of the SEI forming additives, the lithium surface was covered with relatively uniform regions or conglomerates, separated by cracks, of ca. $1-2 \mu \mathrm{m}$ in dimension (SEI layer).

4. The electrochemical formation of SEI protects the Li| electrolyte system against its aging (the resistance and total impedance evolution with time is much smaller).

Acknowledgments Support of grant 31-242/2012 DS-PB is gratefully acknowledged.

Open Access This article is distributed under the terms of the Creative Commons Attribution License which permits any use, distribution, and reproduction in any medium, provided the original author(s) and the source are credited.

\section{References}

1. Wakihara M, Yamamoto O (1998) Lithium ion batteries. Wiley$\mathrm{VCH}$, Weinheim

2. Scrosati B, Garche J (2010) J Power Sources 195:2419-2430

3. Aurbach D (2000) J Power Sources 89:206-218

4. Aurbach D (2002) In: van Schalkwijk WA, Scrosati B (eds) Advances in lithium-ion batteries. Kluwer, New York

5. Edström K, Herstedt M, Abraham DP (2006) J Power Sources $153: 380-384$

6. Zhang SS (2006) J Power Sources 162:1379-1394

7. Aurbach D, Markovsky B, Salitra G, Markevich E, Taluossef Y, Koltypin M, Nazar L, Ellis B, Kovacheva D (2007) J Power Sources 165:491-499

8. Verma P, Maire P, Novak P (2010) Electrochim Acta 55:63326341

9. Webber A, Blomgren GE (2002) In: van Schalkwijk AW, Scrosati B (eds) Advances in lithium-ion batteries. Kluwer, New York

10. Galinski M, Lewandowski A, Stepniak I (2006) Electrochim Acta 51:5567-5580

11. Lewandowski A, Swiderska-Mocek A (2009) J Power Sources 194:601-609

12. Guerfi A, Dontigny M, Charest P, Petitclerc M, Lagace M, Vijh A, Zaghib K (2010) J Power Sources 195:845-852

13. Kinoshita SC, Kotato M, Sakata Y, Ue M, Watanabe Y, Morimoto H, Tobishima SI (2008) J Power Sources 183:755-760

14. Lewandowski A, Kurc B, Stepniak I, Swiderska-Mocek A (2011) Electrochim Acta 56:5972-5978

15. Xu K (2004) Chem Rev 104:4303-4417

16. Chen L, Wang K, Xie X, Xie J (2007) J Power Sources 174:538-543
17. Buqa H, Golob P, Winter M, Besenhard JO (2001) J Power Sources 97-98:122-125

18. Andreson AM, Edström K (2001) J Electrochem Soc 148:A1100 A1109

19. Lewandowski A, Acznik I (2010) Electrochim Acta 56:211-214

20. Xiong S, Kai X, Hong X, Diao Y (2011) Ionics. doi:10.1007? s11581-011-0628-1

21. Umeda GA, Menke E, Richard M, Stamm KL, Wudl F, Dunn B (2011) J Mater Chem 21:1593-1599

22. Ding F, Hu X, Liu Y (2007) Journal of Wuhan University of Technology-Mater Sci Ed 22:494-498

23. Chang CC, Hsu SH, Jung YF, Yang CH (2011) J Power Sources 196:9605-9611

24. Zheng H, Jiang K, Abe T, Ogumi Z (2006) Carbon 44:203-210

25. Holzapfel M, Jost C, Novak P (2004) Chem Commun 2098-2099

26. Sun HG, Dai S (2010) Electrochim Acta 55:4618-4626

27. Holzapfel M, Jost C, Prodi-Schwab A, Krumeich F, Wursig A, Buqa H, Novak P (2005) Carbon 43:1488-1498

28. Lux SF, Schmuck M, Jeong S, Passerini S, Winter M, Balducci A (2010) Int J Energy Res 34:97-106

29. Zheng H, Li B, Fu Y, Abe T, Ogumi Z (2006) Electrochim Acta 52:1556-1562

30. Fu Y, Chen C, Qiu C, Ma X (2009) J Appl Electrochem 39:25972603

31. Abe K, Miyoshi K, Hattori T, Ushigoe Y, Yoshitake H (2008) J Power Sources 184:449-455

32. Lee HH, Wang YY, Wan CC, Yang MH, Wu HC, Shieh DT (2005) J Appl Electrochem 35:615-623

33. Itagaki M, Yotsuda S, Kobari N, Watanabe K, Kinoshita S, Ue M (2006) Electrochim Acta 51:1629-1635

34. Ota H, Sato T, Suzuki H, Usami T (2001) J Power Sources $97-$ 98:107-113

35. Itagaki M, Kobari N, Yotsuda S, Watanabe K, Kinoshita S, Ue M (2005) J Power Sources 148:78-84

36. Sun X, Angell CA (2009) Electrochem Commun 11:1418-1421

37. Shim EG, Nam TH, Kim JG, Kim HS, Moon SI (2007) Electrochim Acta 53:650-656

38. Shim EG, Nam TH, Kim JG, Kim HS, Moon SI (2007) J Power Sources 172:901-907

39. Sato T, Maruo T, Marukane S, Takagi K (2004) J Power Sources $138: 253-261$

40. Santee S, Xiao A, Yang L, Gnanaraj J, Lucht BL (2009) J Power Sources 194:1053-1060

41. Choi NS, Lee Y, Kim SS, Shin SC, Kang YM (2010) J Power Sources 195:2368-2371

42. Kim J, Song SW, Van Hoang H, Doh CH, Kim DW (2011) Bull Korean Chem Soc 32:105-108

43. Lewandowski A, Świderska-Mocek A, Acznik I (2010) J Appl Electrochem 40:1619-1624

44. Nadherna M, Reiter J, Moskon J, Dominko R (2011) J Power Sources 196:7700-7706 